\title{
PERFORMANCE EVALUATION OF HYBRID FIBRE REINFORCED CONCRETE SUBJECTED TO FREEZING AND THAWING EFFECT
}

\author{
K.Ravi ${ }^{1}$, A.V.Karvekar ${ }^{2}$ \\ ${ }^{I}$ Director \& Professor, Department of Civil Engineering, Ashokrao Mane Group of Institutions, Vathar tarf Vadgaon, \\ Kolhapur, Maharashtra, India \\ ${ }^{2}$ Assistant Professor, Department of Civil Engineering, Ashokrao Mane Group of Institutions, Vathar tarf Vadgaon, \\ Kolhapur, Maharashtra, India
}

\begin{abstract}
Durability is the ability to last a long time without significant deterioration. Hybrid fiber reinforced concrete (HFRC) proves to be durable material, which is effective in resisting the damage caused due to freezing and thawing due to synergistic performance of hybrid fibers. The objectives of the work described in this paper were aimed at comparing the relative strength of Hybrid fiber reinforced concrete (HFRC) with that of mono fiber reinforced concrete (FRC) and plain concrete without fibers (ref. mix) subjected to freezing and thawing. The combination of fibers used in the experimentation are (Steel + Polypropylene),(Steel +Galvanized Iron),(Steel + High density polyethylene).Strength parameters considered are compressive strength, split tensile strength, flexural strength and impact strength and tested as per relevant IS specifications. It has been concluded that the performance of hybrid fibers in concrete is better than that of mono fiber concrete for improved durability in resisting the destructive effect of freezing and thawing and also for strength enhancement.
\end{abstract}

Keywords: Fiber reinforced concrete, hybrid fiber reinforced concrete, freezing and thawing, frost action, synergic effect.

\section{INTRODUCTION}

Concrete structures should be designed and performed in the way that, under expected environmental conditions, their safety and usability hold over the structure's lifetime with minimal repair and maintenance costs. In cold climates, damage to concrete pavements, retaining walls, bridge decks, and railings are due to frost actions (freezing and thawing). Deterioration of concrete from freeze thaw actions may occur when the concrete is critically saturated, which is when approximately $91 \%$ of its pores are filled with water. When water freezes to ice it occupies $9 \%$ more volume than that of water. If there is no space for this volume expansion in a porous, water containing material like concrete, freezing may cause distress in the concrete. One of the factors which control the frost resistance of concrete is the degree of saturation, as dry or partially dry substances do not suffer frost damage. A concrete may fail below the critical degree of saturation after adequate curing, but depending on the permeability it may again reach or exceed the critical degree of saturation if exposed to moist environment [1]. The reduction of permeability can be enhanced by controlling the width of the crack. The crack width limits for an aggressive environment are so low that they are generally difficult to achieve in practice using common reinforcing steel and conventional concrete due to incompatible tensile deformation of concrete with steel in RC structures [2]. Fibers are incorporated in concrete to improve shrinkage and permeability resistance of concrete, which are two important parameters related to durability of concrete [5]. Most fiber-reinforced concrete used in practice contains only one type of fiber. It is known that failure in concrete is a gradual, multi-scale process. The pre-existing cracks in concrete are of the order of microns. Under an applied load, these cracks grow and eventually join together to form macro cracks. A macro crack propagates at a stable rate until it attains conditions of unstable propagation and a rapid fracture is precipitated. The gradual and multi-scale nature of facture in concrete implies that a given fiber can provide reinforcement only at one level and within a limited range of strains [6]. Therefore one idea gaining much attention lately is that of fiber hybridization. In a hybrid, two or more different types of fibers are rationally combined to produce a composite that derives benefits from each of the individual fibers and exhibits a synergistic response. The basic purpose in using hybrid fibers is to control cracks at different size levels, in different zones of concrete (cement paste or interface zone between paste and aggregate), at different curing ages and at different loading stages. The large and the strong fibers control large cracks. The small and soft fibers control crack initiation and propagation of small cracks [7].

The main objective of this experimentation is to study the strength behavior of hybrid fiber reinforced concrete and mono fiber reinforced concrete subjected to freezing and thawing. The combination of fibers used in the experimentation is (Steel +Polypropylene Steel +Galvanized Iron), (Steel+High density polyethylene). The various strength parameters studied are compressive strength, split tensile strength, flexural strength and impact strength. 


\section{RESEARCH SIGNIFICANCE}

Long-life concrete must be resistant to destruction when exposed to aggressive environment like the freezing effect with or without deicing salt. Earlier air entraining agents are adopted to minimize the effect of freezing. At present utility of hybrid fiber reinforced concrete to enhance strength and durability when subjected to freezing and thawing is not explored to a greater extent. Therefore there is need for research to study the synergistic response of hybrid fibers in concrete for strength enhancement, modification of crack pattern and to enhance the durability when structures are exposed to freezing and thawing action.

\section{MATERIALS}

OPC 43 grade (confirming to IS 8112) with specific gravity 3.15. Sand used was of zone III and its specific gravity was 2.60. Coarse aggregates used in experimentation were $12 \mathrm{~mm}$ and down size and their specific gravity was found to be 2.75. Different fibers used in the study are Steel fibers (SF), Galvanized iron fiber (GIF), Polypropylene fibers (PPF) and high density poly ethylene fibers (HDPEF). Physical properties of fibers are presented in Table-1. Mono fibers were added at the rate of $1.5 \%$ (by volume fraction). Hybrid fibers were added at the rate of $(0.75 \%+0.75 \%)$. Different combination of fibers considered are $(\mathrm{SF}+\mathrm{GIF}),(\mathrm{SF}+\mathrm{PPF})$, and (SF+HDPEF). Mix proportion used for M25 concrete was 1:1.28:2.87 with w/c $=0.45$ (IS10262:1982). The quantities are shown in Table- 2. Cube

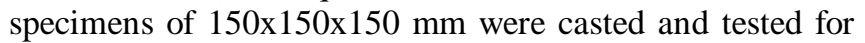
compressive strength as per IS: 516-1959. Cylindrical specimens $150 \mathrm{mmX} 300 \mathrm{~mm}$ were casted and tested for split tensile strength as per IS: 5816-1999. Beam specimens of $100 \times 100 \times 500 \mathrm{~mm}$ were casted and tested for flexural strength as per IS: 516-1959. A mild steel ball weighing $12.20 \mathrm{~N}$ was dropped from a height of one meter on the impact specimen of dimension $250 \times 250 \times 30 \mathrm{~mm}$, which was kept on the floor to determine impact strength in N-m. After their 28 days of curing the specimens were transferred to a cold storage unit for freezing and thawing wherein a temperature of $-18{ }^{\circ} \mathrm{C}$ was maintained. After 24 hours they were taken out of cold storage and kept in water for 24 hours. This constituted one cycle of freezing and thawing. The specimens were subjected to 45 cycles of freezing and thawing in total. Then these specimens were tested for respective strengths.

Table- 1: Properties of fibers used

\begin{tabular}{|l|l|l|l|l|}
\hline Fiber type & $\begin{array}{l}\text { Length } \\
(\mathrm{mm})\end{array}$ & Thickness & $\begin{array}{l}\text { Aspect } \\
\text { ratio }\end{array}$ & $\begin{array}{l}\text { Density } \\
\left(\mathrm{N} / \mathrm{m}^{3}\right)\end{array}$ \\
\hline $\begin{array}{l}\text { Steel fiber } \\
\text { (SF) }\end{array}$ & 40 & $1 \mathrm{~mm}$ & 40 & 78500 \\
\hline $\begin{array}{l}\text { Polypropylene } \\
\text { fiber (PPF) }\end{array}$ & 12 & $7.5 \mu \mathrm{m}$ & 1600 & 9100 \\
\hline $\begin{array}{l}\text { Galvanized } \\
\text { iron fiber(GIF) }\end{array}$ & 50 & $1 \mathrm{~mm}$ & 50 & 64000 \\
\hline $\begin{array}{l}\text { High density } \\
\text { polyethylene } \\
\text { fibers(HDPEF) }\end{array}$ & 50 & $1.5 \mathrm{~mm}$ & 35 & 1210 \\
\hline
\end{tabular}

Table- 2: Mix proportion for reference mix

\begin{tabular}{|l|l|l|l|}
\hline Material & $\begin{array}{l}\text { Quantity } \\
\mathrm{Kg} / \mathrm{m}^{3}\end{array}$ & Material & $\begin{array}{l}\text { Quantity } \\
\mathrm{Kg} / \mathrm{m}^{3}\end{array}$ \\
\hline Cement & 425.7 & Water & 191.5 \\
\hline Fine aggregate & 544 & SP & 0.425. \\
\hline Coarse aggregate & 1223 & w/c & 0.45 \\
\hline
\end{tabular}

\section{RESULTS}

Table- 3 and 4 gives the overall results of compressive strength (Comp. Stg.), split tensile strength (Ten. Stg.), flexural strength (Flex. Stg.) and impact strength (Impact Stg.) of hybrid and mono fiber reinforced concrete with and without subjecting to freezing and thawing.

Table- 5 gives overall results of percentage decrease in compressive strength, tensile strength, flexural strength \& impact strength of HFRC and mono fibre reinforced concrete when subjected to 45 cycles of freezing and thawing.

The variation in the compressive strength, split tensile strength, flexural strength and impact strength is presented in the form of graph as shown in Fig.- 1, 2, 3 and 4.

Table- 3: Overall results of compressive strength, tensile strength, flexural strength \& impact strength of HFRC and mono fibre reinforced concrete.

\begin{tabular}{|l|l|l|l|l|}
\hline \multirow{2}{*}{ Description } & \multicolumn{4}{|l}{$\begin{array}{l}\text { Strength without subjecting to freezing } \\
\text { and thawing (MPa) }\end{array}$} \\
\cline { 2 - 5 } & $\begin{array}{l}\text { Comp. } \\
\text { Stg. }\end{array}$ & $\begin{array}{l}\text { Ten. } \\
\text { Stg. }\end{array}$ & $\begin{array}{l}\text { Flex. } \\
\text { Stg. }\end{array}$ & $\begin{array}{l}\text { Impa. } \\
\text { Stg. }\end{array}$ \\
\hline $\begin{array}{l}\text { Reference mix } \\
(\text { No fibers })\end{array}$ & 27.80 & 3.10 & 4.10 & 73.2 \\
\hline $\begin{array}{l}\text { SF +GIF } \\
(0.75 \%+0.75 \%)\end{array}$ & 52.60 & 6.20 & 7.00 & 951.6 \\
\hline $\begin{array}{l}\text { SF +PPF } \\
(0.75 \%+0.75 \%)\end{array}$ & 44.80 & 4.80 & 5.30 & 646.6 \\
\hline $\begin{array}{l}\text { SF + HDPEF } \\
(0.75 \%+0.75 \%)\end{array}$ & 46.20 & 5.20 & 5.72 & 719.8 \\
\hline SF (1.5\%) & 47.82 & 5.90 & 6.40 & 878.4 \\
\hline GIF (1.5\%) & 45.70 & 5.15 & 5.70 & 585.6 \\
\hline PPF (1.5\%) & 43.10 & 4.20 & 4.80 & 219.2 \\
\hline HDPEF (1.5\%) & 44.28 & 4.7 & 5.30 & 317.2 \\
\hline
\end{tabular}

Table- 4: Overall results of compressive strength, tensile strength, flexural strength \& impact strength of HFRC and mono fibre reinforced concrete when subjected to 45 cycles of freezing and thawing.

\begin{tabular}{|l|l|l|l|l|}
\hline \multirow{2}{*}{ Description } & \multicolumn{4}{|l}{$\begin{array}{l}\text { Strength when subjected to } 45 \text { cycles of } \\
\text { freezing and thawing (MPa) }\end{array}$} \\
\cline { 2 - 5 } & $\begin{array}{l}\text { Comp. } \\
\text { Stg. }\end{array}$ & $\begin{array}{l}\text { Ten. } \\
\text { Stg. }\end{array}$ & $\begin{array}{l}\text { Flex. } \\
\text { Stg. }\end{array}$ & $\begin{array}{l}\text { Impa. } \\
\text { Stg. }\end{array}$ \\
\hline $\begin{array}{l}\text { Reference mix } \\
\text { (No fibers) }\end{array}$ & 18.18 & 1.80 & 2.80 & 48.8 \\
\hline $\begin{array}{l}\text { SF +GIF } \\
(0.75 \%+0.75 \%)\end{array}$ & 40.00 & 4.76 & 5.42 & 756.4 \\
\hline $\begin{array}{l}\text { SF +PPF } \\
(0.75 \%+0.75 \%)\end{array}$ & 34.36 & 3.80 & 4.00 & 390.4 \\
\hline SF + HDPEF & 37.42 & 4.10 & 4.60 & 463.6 \\
\hline
\end{tabular}




\begin{tabular}{|l|l|l|l|l|}
\hline$(0.75 \%+0.75 \%)$ & & & & \\
\hline SF $(1.5 \%)$ & 38.24 & 4.28 & 5.22 & 658.8 \\
\hline GIF $(1.5 \%)$ & 36.12 & 4.00 & 4.80 & 451.4 \\
\hline PPF $(1.5 \%)$ & 32.12 & 3.30 & 3.40 & 164.4 \\
\hline HDPEF $(1.5 \%)$ & 34.10 & 3.60 & 4.20 & 256.2 \\
\hline
\end{tabular}

Table- 5: Overall results of percentage decrease in compressive strength, tensile strength, flexural strength \& impact strength of HFRC and mono fibre reinforced concrete when subjected to 45 cycles of freezing and thawing.

\begin{tabular}{|l|l|l|l|l|}
\hline \multirow{2}{*}{ Description } & \multicolumn{4}{|l|}{$\begin{array}{l}\text { Percentage decrease in Strength when } \\
\text { subjected to freezing and thawing }\end{array}$} \\
\cline { 2 - 5 } & $\begin{array}{l}\text { Comp. } \\
\text { Stg. }\end{array}$ & $\begin{array}{l}\text { Ten. } \\
\text { Stg. }\end{array}$ & $\begin{array}{l}\text { Flex. } \\
\text { Stg. }\end{array}$ & $\begin{array}{l}\text { Impa. } \\
\text { Stg. }\end{array}$ \\
\hline $\begin{array}{l}\text { Reference mix } \\
\text { (No fibers) }\end{array}$ & 34.6 & 41.9 & 31.7 & 33.3 \\
\hline $\begin{array}{l}\text { SF +GIF } \\
(0.75 \%+0.75 \%)\end{array}$ & 23.8 & 23.4 & 22.6 & 20.5 \\
\hline $\begin{array}{l}\text { SF +PPF } \\
(0.75 \%+0.75 \%)\end{array}$ & 23.3 & 21.0 & 24.5 & 39.6 \\
\hline $\begin{array}{l}\text { SF + HDPEF } \\
(0.75 \%+0.75 \%)\end{array}$ & 19.0 & 21.0 & 19.6 & 35.5 \\
\hline SF (1.5\%) & 20.0 & 27.5 & 18.4 & 25.0 \\
\hline GIF (1.5\%) & 21.0 & 22.3 & 15.8 & 22.9 \\
\hline PPF $(1.5 \%)$ & 25.5 & 21.4 & 29.2 & 25.0 \\
\hline HDPEF $(1.5 \%)$ & 23.0 & 24.0 & 20.7 & 19.23 \\
\hline
\end{tabular}

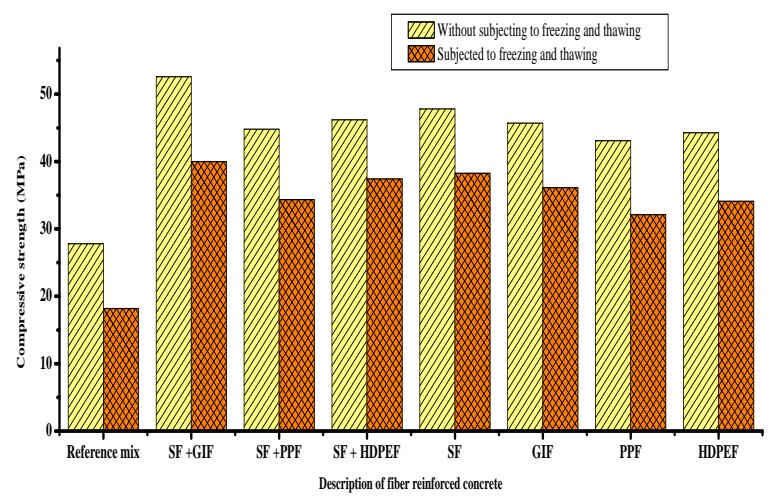

Fig- 1: Variation in compressive strength of HFRC and mono fibre reinforced concrete with and without subjecting to freezing and thawing.

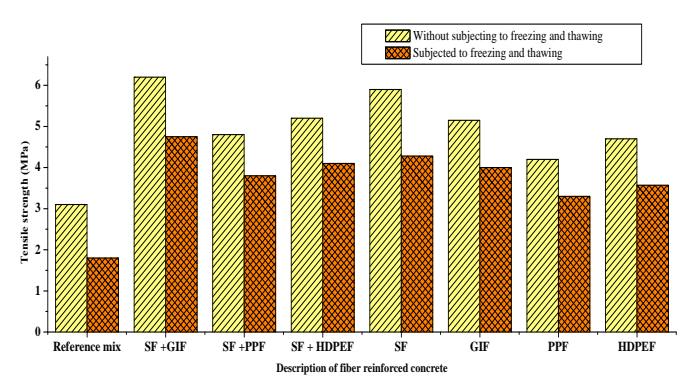

Fig- 2: Variation in tensile strength of HFRC and mono fibre reinforced concrete with and without subjecting to freezing and thawing.

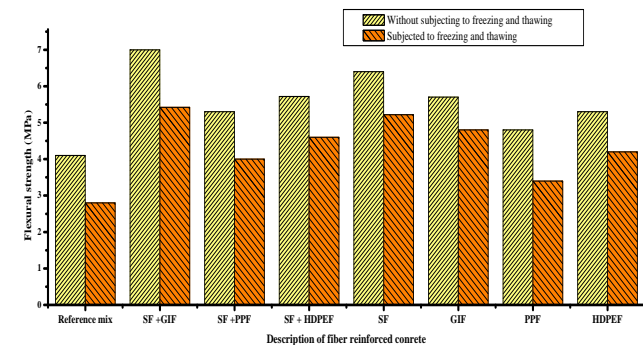

Fig- 3: Variation in flexural strength of HFRC and mono fibre reinforced concrete with and without subjecting to freezing and thawing.

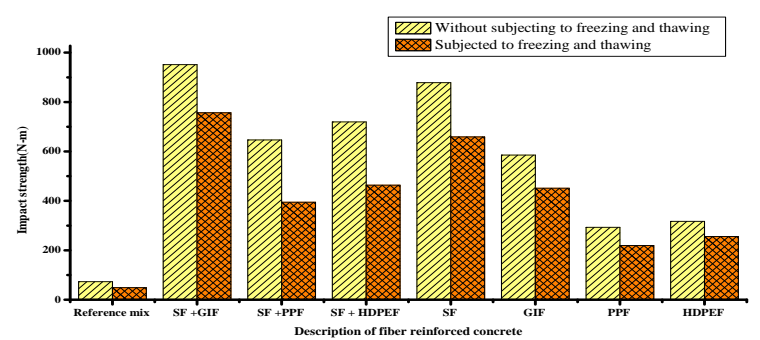

Fig- 4: Variation in impact strength of HFRC and mono fibre reinforced concrete with and without subjecting to freezing and thawing.

\section{DISCUSSION ON TEST RESULTS}

The following observations were made when mono fiber reinforced concrete and hybrid fiber reinforced concrete are subjected to freezing and thawing and tested for various strength characteristics. All mono fiber reinforced concrete and HFRC displayed an increased compressive strength compared to reference mix without fibers when subjected to freezing and thawing cycles. In case of non-metallic fibers like polypropylene and HDPE the increase in compressive strength was found to be $77 \%$ and $88 \%$ respectively with respect to the reference mix. In case of metallic fibers like G.I and steel the increase in strength was up to $99 \%$ and $110 \%$ respectively with respect to reference mix. The HFRC with steel and G.I yielded the highest compressive strength of $40.00 \mathrm{MPa}$ (Fig- 1) and it was $121 \%$ higher the than compressive strength of the reference mix. The higher strength in the case of non-metallic fibers may be due to higher volume fraction of fibers. The higher strength in case of the metallic fibers is due to higher modulli of elasticity of the fibers.

An increase in the tensile strength was observed in mono fiber concrete and hybrid fiber concrete specimens, subjected to freezing and thawing with respect to the reference mix without fibers. There is an increase of $11 \%$ $19 \%$ in the tensile strength in hybrid fiber concrete specimens when compared to respective mono fiber concretes(Fig- 2).The hydraulic pressure due to increase in the volume of water on freezing in large cavities causes tensile stress. The tensile stress can be effectively arrested by hybrid fibers. The cracks are arrested at different levels with different fibers having different modulli of elasticity. This results in higher tensile strength. 
Similar observations were made in case of the flexural strength of mono fiber concretes and hybrid fiber concretes subjected to freezing and thawing. An enhancement in the flexural strength up to $18 \%$ was observed in hybrid fiber concrete produced with $(\mathrm{SF}+\mathrm{PPF})$ fibers in comparison to mono fiber concrete with polypropylene fibers (Fig- 3). The improvement in flexural strength is very essential for highway pavements in cold climates exposed to freezing and thawing actions.

It was observed that the concretes with hybrid blend of metallic fibers and non-metallic fibers like (SF+PPF) and (SF+HDPE) are found to be very effective for the impact resistance when subjected to freezing and thawing (Fig- 4). An enhancement up to $1375 \%$ was observed in impact strength of (SF+HDPEF) w.r.t impact strength of reference mix. This is because of the difference in the modulli of elasticity of metallic and non-metallic fibers. The nonmetallic fibers with low modulus of elasticity are responsible for the impact strength for first failure and higher modulus fibers like metallic fibers are effective in enhancement of final failure strength.

\section{CONCLUSIONS}

- The mechanical properties of concrete can be improved by introducing hybrid fibers in concrete exposed to freezing and thawing

- All mono fiber concrete and hybrid fiber reinforced concretes displayed higher strength compared to the strength of reference mix without fibers when exposed to freezing and thawing

- $\quad$ The hybrid fibers are found to be effective in resisting the tensile stresses caused by destructive action of freezing and thawing

- $\quad$ The hybrid blends of metallic and non-metallic fibers have shown considerable improvement in the impact resistance when subjected to freezing and thawing. An enhancement up to $1375 \%$ was observed in impact strength of (SF+HDPEF) w.r.t impact strength of reference mix. This property of concrete would qualify to be a good pavement material in cold regions

- The durability of concrete against freezing and thawing can be enhanced by introducing hybrid fibers into concrete.

\section{ACKNOWLEDGEMENTS}

The authors would like to express their sincere thanks to Dr. K. B. Prakash, Principal, Government College of Engineering, Haveri, Karanataka., Prof. D. N. Mudgal, Executive Director, A.M.G.O.I., Vathar tarf Vadgaon, Maharashtra, India and all the Management authorities of Shri Balasaheb Mane Shikshan Prasarak Mandal, Ambap, Kolhapur, Maharashtra, India who constantly boosted the moral support.

\section{REFERENCES}

[1]. Kumar Mehta P., Paulo Monterio J.M., "Concrete Microstructure, Properties and Materials." Tata McGrawHill Publishing Company Limited. New-Delhi. 2006 Edition.

[2]. Shaikh Faiz Uddin Ahemed, Hirazo Mihashi, "A Review of Durability Properties of Strain Hardening Fiber Reinforced Cementitious Composites (SHFRCC)." Cement and Concrete Composites, vol.29,2007,pp365-376.

[3]. Sun W., Chen H., Luo X., Qian H., "The Effect of Hybrid Fibers and Expansive Agent on the Shrinkage and Permeability of High-Performance Concrete". Cement and Concrete Research, Vol.31, 2001, pp 595 -601.

[4]. Lawler, John S. Zampini, Davide; Shah, Surendra P. "Permeability of Cracked Hybrid Fiber-Reinforced Mortar Under Load." ACI Materials Journal, V01 99, No. 4, July/August, 2002, pp 379-385.

[5]. Sivakumar, A. Santhanam, Manu: “A Quantitative Study on the Plastic Shrinkage Cracking in High Strength Hybrid Fibre Reinforced Concrete" Cement and Concrete Composites, Vol. 29, No. 7, August, 2007, pp 575-581.

[6]. Banthia, N, Gupta, R.. "Hybrid Fiber Reinforced Concrete (HFRC): Fiber Synergy in High Strength Matrices. "Materials And Structures, Vol. 37, No 274, December, pp 707-716. 2004.

[7]. Chunxiang Qian, Piet Stroven, "Fracture Properties of Concrete Reinforced with Steel-Polypropylene Hybrid Fibres", Cement and Concrete Composites, Vol. 22, pp 343-351. 2000.

[8]. IS: 8112-1989: Specification for 43 Grade Ordinary Portland Cement.

[9]. IS: 383-1970: Specification for coarse and fine aggregates from natural sources for concrete.

[10]. IS: 2386 (Part-I,II, III and IV) -1963: Method of tests for aggregates for concrete.

[11]. IS: 516-1959: Method of test for strength of concrete.

[12]. IS: 5816-1999: Splitting tensile strength of concrete method of test.

[13]. IS 10262-1982: Recommended guide lines for concrete mix design.

\section{BIOGRAPHIES}

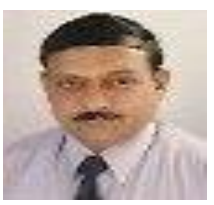

He has obtained $\mathrm{Ph}$. D. from V.T.U. Belgaum, Karanataka, India. He has vast teaching \& research experience in various fields of civil engineering. He is working as Director and Professor at Ashokrao Mane Group of Institutions, Vathar tarf Vadgaon, Maharashtra, India. Formerly he was working as scientist in National Institute of Oceanography, Goa, India. His research interests are in the field of concrete technology and wave mechanics.

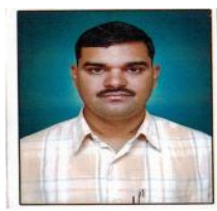

He has obtained M.Tech in structural engineering \& persuing Ph.D. from from V.T.U. Belgaum, Karanataka, India. He is working as Head \& Assistant Professor of civil engineering department at Ashokrao Mane Group of Institutions, Vathar tarf Vadgaon, Maharashtra, India 